\title{
Tantangan, Harapan, dan Peluang Tadris Matematika dalam Mewujudkan Guru Matematika yang Islami, Profesional, dan Kompetitif
}

\author{
Mutia $^{1}$, Wiwin Arbaini Wahyuningsih ${ }^{2}$ \\ ${ }^{1,2}$ Institut Agama Islam Negeri Curup \\ ${ }^{1}$ mutia@iaincurup.ac.id, ${ }^{2}$ wiwin721004@gmail.com
}

\begin{tabular}{l}
\hline \hline Article Info \\
\hline Article history: \\
Received Agt $4^{\text {th }}, 2019$ \\
Revised Oct $23^{\text {th }}, 2019$ \\
Accepted Nov $30^{\text {th }}, 2019$ \\
\hline
\end{tabular}

Keywords:

Challenges;

Hopes;

Opportunities
Abstract

In line with the vision of the Mathematics Tadris Study Program at the IAIN Curup, the Mathematics Tadris IAIN is required to be able to organize tadris and teaching in the field of Mathematics Tadris professionally in order to produce educators in the field of Mathematics Tadris who have high morality and are able to compete in the world of tadris. To realize the Islamic, professional, and competitive mathematics teacher is not an easy thing for Mathematics Tadris. Many challenges and obstacles will be felt Mathematics Tadris to achieve it all. Therefore, it is necessary to analyze the strengths and weaknesses of Mathematics Tadris study programs to anticipate challenges and create opportunities using SWOT. The main sources in data collection are plt. Head of Tarbiyah Department, plt. Head of Mathematics Tadris, Staff of Mathematics Tadris, lecturers at IAIN Curup, and students of Mathematics Tadris IAIN Curup. Strategies undertaken to realize Islamic, professional, and competitive teachers include the development of Islamic teaching materials that are integrated with Islam, linking them with the holy verses of the Qur'an and Hadith; instill character values to students such as a sense of responsibility and sincerity in completing assignments given by lecturers, independent, honest, and disciplined; give an example to students by greeting and being friendly to students and being fair; establish good relationships with students; be a good example in social life; creating lectures that are full of warmth and fun; provide an objective assessment of students and improve student scientific competence, especially in mathematical science. 
144 | Mutia dan Arbaini: Tantangan, Harapan, dan Peluang Tadris Matematika...

Kata Kunci:

Tantangan;

Harapan;

Peluang

\section{Abstrak}

Sejalan dengan Visi Program Studi Tadris Matematika Jurusan Tarbiyah IAIN Curup, maka Tadris Matematika IAIN dituntut untuk dapat menyelenggarakan tadris dan pengajaran di bidang Tadris Matematika secara profesional dalam rangka melahirkan tenaga pendidik di bidang Tadris Matematika yang memiliki moralitas tinggi serta mampu bersaing dalam dunia tadris. Untuk mewujudkan guru matematika yang islami, profesional, dan kompetitif tersebut bukanlah suatu hal yang mudah bagi Tadris Matematika IAIN Curup. Banyak tantangan dan hambatan yang akan dirasakan Tadris Matematika untuk mencapai itu semua. Oleh sebab itu, perlu dilakukan analisis kekuatan dan kelemahan prodi Tadris Matematika untuk mengantisipasi tantangan dan menciptakan sebuah peluang dengan menggunakan teknik analisa data yaitu analisis deskriptif kualitatif dan analisis SWOT yang terdiri dari Strengths (kekuatan), Weakness (kelemahan), Opportunities (peluang), dan Threats (ancaman). Sumber utama pengumpulan data dalam penelitian ini adalah Plt. Ketua Jurusan Tarbiyah, Plt. Penanggung Jawab Prodi Tadris Matematika, Staff Prodi Tadris Matematika, dosen matematika IAIN Curup, dan mahasiswa Tadris Matematika IAIN Curup. Strategi yang dilakukan untuk mewujudkan guru yang islami, profesional, dan kompetitif diantaranya pengembangan bahan ajar matematika yang terintegrasi keislaman, menghubungkannya dengan ayat-ayat suci Alquran dan hadis; menanamkan nilai-nilai karakter kepada mahasiswa seperti rasa tanggung jawab dan ikhlas dalam menyelesaikan tugas yang diberikan dosen, mandiri, jujur, dan disiplin; memberikan keteladanan kepada mahasiswa dengan mengucapkan salam dan bersikap ramah kepada mahasiswa dan bersikap adil; menjalin hubungan yang baik dengan mahasiswa; menjadi contoh yang baik dalam kehidupan bermasyarakat; menciptakan perkuliahan yang penuh kehangatan dan menyenangkan; memberikan penilaian yang objektif kepada mahasiswa dan meningkatkan kompetensi keilmuan mahasiswa khususnya pada keilmuan matematika. 


\section{PENDAHULUAN}

Menyadari sebagai satu-satunya Perguruan Tinggi Islam Negeri yang ada di Kabupaten Rejang Lebong, maka IAIN perlu mengakomodir kebutuhan masyarakat sekitar terutama dalam mencetak SDM yang memiliki kualifikasi sarjana, terutama sarjana pendidik. Sebagai lembaga tadris tinggi memiliki tanggung jawab moral untuk turut serta mempersiapkan SDM yang berkualitas, baik untuk kepentingan IAIN maupun untuk kepentingan lembaga-lembaga pelayanan masyarakat lainnya.

Sejalan dengan kebutuhan masyarakat dan tuntutan politik tadris dewasa ini, perguruan tinggi Islam senantiasa menyelesaikan dengan berbagai multi dimensi. Tuntutan dan kondisional kebutuhan terhadap sumber daya manusia terutama berkaitan dengan pembangunan tadris, mulai disahuti oleh kehadiran dan perkembangan Jurusan Tarbiyah dalam lingkungan Perguruan Tinggi Islam. Salah satu ujung tombak keberhasilan dan pendukung Jurusan Tarbiyah itu adalah kehadiran Program Studi Tadris Matematika.

Sejalan dengan Visi Program Studi Tadris Matematika Jurusan Tarbiyah IAIN Curup yaitu: Pada tahun 2037 menjadi Program Studi bermutu dan terkemuka dalam menghasilkan Pendidik Matematika yang islami, profesional, dan kompetitif pada jenjang tadris menengah, maka Program Studi Tadris Matematika IAIN dituntut untuk dapat menyelenggarakan tadris dan pengajaran di bidang Tadris Matematika secara profesional dalam rangka melahirkan tenaga pendidik di bidang Tadris Matematika yang memiliki moralitas tinggi serta mampu bersaing dalam dunia tadris. Berdirinya Program Studi Tadris Matematika ini dapat menjadi salah satu pilar unifikasi antara ilmu-ilmu agama dan ilmu sains dan teknologi.

Matematika merupakan salah satu cabang sains yang sangat sulit untuk dipelajari siswa maupun mahasiswa khususnya di perguruan tinggi keislaman seperti IAIN Curup. Menyadari hal tersebut, maka Tadris Matematika di bawah Jurusan Tarbiyah (saat ini Fakultas Tarbiyah) terus berupaya meningkatkan kualitas dan kuantitas program studinya. Menurut 
146 | Mutia dan Arbaini: Tantangan, Harapan, dan Peluang Tadris Matematika...

Kosim (2009), penyelenggaraan jurusan tadris di IAIN/STAIN menghadapi problema kualitas. Selama ini IAIN dikenal sebagai institusi pendidikan tinggi yang fokus pada kajian-kajian agama. Di bidang ini, banyak ahli yang mumpuni dan masyarakat mengakuinya. Ketika lembaga ini juga menyelenggarakan jurusan umum, kompetensinya diragukan terutama jika dibandingkan dengan perguruan tinggi umum, baik kompetensi sumber daya manusia maupun sumber daya lainnya. berat bagi IAIN/STAIN untuk membuktikan kepada masyarakat bahwa mereka bisa memberikan layanan yang lebih baik, paling tidak setara, dengan perguruan tinggi umum dalam penyelenggaraan jurusan-jurusan umum. Karena itu, menjadi tantangan bagi prodi tadris matematika ini untuk membuktikan hal tersebut.

Kualitas tadris di negara berkembang di Asia Pasifik, Indonesia menempati peringkat 10 dari 14 negara. Sedangkan untuk kualitas para guru, kualitasnya berada pada level 14 dari 14 negara berkembang. Salah satu faktor rendahnya kualitas tadris di Indonesia adalah karena lemahnya para guru dalam menggali potensi anak. Para pendidik seringkali memaksa kehendaknya tanpa pernah memperhatikan kebutuhan, minat, dan bakat yang dimiliki siswanya. Tadris seharusnya memperhatikan kebutuhan siswanya bukan justru memaksakan sesuatu yang membuat siswa kurang nyaman dalam menuntut ilmu. Proses tadris yang baik adalah dengan memberikan kesempatan para siswa untuk kreatif, itu harus dilakukan sebab pada dasarnya gaya berpikir siswa tidak bisa diarahkan. Hal ini tentunya sangat berkaitan dengan strategi guru dalam menyampaikan materi dengan memperhatikan kebutuhan siswa.

Secara lanjut mengenai jumlah guru matematika yang masih sangat sedikit sehingga banyak guru yang bukan bidangnya mengajarkan matematika. Hal ini tentu merupakan salah satu masalah besar dalam tadris. Bagaimana mungkin guru yang bukan latar belakangnya matematika mengajarkan matematika kepada siswanya, memahami kebutuhan, bakat, minat, dan kemampuan berpikir siswa, dan bagaimana mungkin guru tersebut juga mampu menyelesaikan masalah kesulitan belajar matematika siswa dengan baik jika gurunya saja tidak memiliki 
dasar tentang itu dan tidak memiliki strategi yang tepat. Di Rejang Lebong, sudah hampir 7 tahun (dari tahun 2010), pemerintah pusat tidak merekrut kembali calon guru-guru di madrasah melalui tes Calon Pegawai Negeri Sipil (CPNS) sehingga kebutuhan akan guru sangat dibutuhkan terutama guru matematika karena matematika adalah salah satu mata pelajaran yang sangat penting. Ini menunjukkan bahwa Sumber Daya Manusia (SDM) negara kita juga masih sangat kurang padahal SDM merupakan salah satu faktor penentu keberhasilan tadris di Indonesia. Guru memang bukan satu-satunya sumber belajar siswa, akan tetapi gurulah yang menjadi ujung tombak proses pembelajaran. Adapun faktorfaktor yang mempengaruhi dalam upaya mencetak para lulusan yang berkualitas dengan prestasi belajar yang tinggi meliputi pendidik (guru), peserta didik, kurikulum, metode, media/alat bantu, evaluasi, dan lingkungan (Siti, 2016).

Tuntutan guru tidak hanya sekedar kemampuan menguasai pelajaran saja, akan tetapi juga kemampuan lainnya yang terangkum dalam 4 kompetensi guru yaitu kompetensi profesional, kompetensi personal, kompetensi pedagogik, dan kompetensi sosial sehingga mampu menarik perhatian siswa dalam proses pembelajaran. Tadris Matematika di IAIN Curup tidak hanya berharap empat kompetensi tersebut dapat tercapai, akan tetapi juga berharap lulusan tadris matematika adalah lulusan yang berkualitas tidak hanya berkualitas dalam penguasaan pengetahuan (kognitif) tetapi juga memiliki nilai-nilai islami sehingga terwujud guru matematika yang islami, profesional, dan kompetitif.

Tujuan penelitian ini adalah untuk mengetahui kekuatan dan kelemahan dari program studi tadris matematika dalam mewujudkan guru matematika yang islami, profesional, dan kompetitif serta untuk mengetahui strategi apa yang dilakukan oleh program studi untuk mengatasi kelemahan tersebut.

\section{METODE PENELITIAN}

Penelitian ini menggunakan pendekatan kualitatif deskriptif. Penelitian kualitatif adalah penelitian yang bermaksud untuk memahami 
148 | Mutia dan Arbaini: Tantangan, Harapan, dan Peluang Tadris Matematika...

fenomena tentang apa yang dialami subjek penelitian secara holistik, dan dengan cara deskripsi dalam bentuk kata-kata dan bahasa, dengan kata lain yaitu merupakan uraian naratif mengenai suatu proses tingkah laku subjek sesuai dengan masalah yang diteliti dan temuan-temuan penelitian berupa data maupun informan (Haryono, 1998).

Peneliti mencermati fenomena-fenomena yang terjadi untuk mengembangkan temuan-temuan yang dijadikan dasar atau bukti yang tidak diragukan dan memformulasikan upaya-upaya yang dilakukan Tadris Matematika untuk mengubah tantangan tadris matematika dan pembelajaran matematika menjadi sebuah peluang yang besar dalam mewujudkan guru yang islami, kompetitif, dan profesional. Adapun fenomena yang terjadi tersebut berupa masih rendahnya hasil pembelajaran matematika yang menunjukkan sebagian besar siswa yang belum cinta matematika, serta masih keringnya nilai pembelajaran matematika yang disebabkan oleh kurangnya kemampuan profesionalisme guru dan keengganan belajar siswa, serta banyak siswa masih merasa gamang belajar matematika.

Peneliti mengumpulkan data dari latar yang sesungguhnya sebagai sumber data langsung secara lengkap menggunakan metode triangulasi melalui wawancara, observasi, dokumentasi dan lain-lain yang diperoleh dari key informan.

Sampel sumber data dalam penelitian kualitatif dipilih secara purposive dan bersifat snowball sampling. Penentuan sampel sumber data pada proposal masih bersifat sementara dan akan berkembang kemudian setelah peneliti di lapangan. Sampel sumber data pada tahap awal memasuki lapangan dipilih orang yang memiliki power dan otoritas pada situasi sosial atau objek yang diteliti, sehingga mampu membukakan pintu kemana saja peneliti akan melakukan pengumpulan data (Sugiyono,2016).

Sumber data dalam penelitian ini adalah Plt. Ketua Jurusan Tarbiyah IAIN Curup, Plt. Penanggung Jawab Prodi Tadris Matematika IAIN Curup, Staff Prodi Tadris Matematika, dosen matematika IAIN Curup, guru matematika SMP/MTs dan SMA/MA, siswa yang mendapat 
pembelajaran matematika, mahasiswa IAIN Curup, Kepala Sub bidang Madrasah, Kabid bidang SMP Dinas Tadris dan Kebudayaan Kabupaten Rejang Lebong dan Kabupaten Kepahiang.

Teknik analisa data yang digunakan dalam penelitian ini adalah analisis deskriptif kualitatif dan analisis SWOT yang terdiri dari Strengths (kekuatan), Weakness (kelemahan), Opportunities (peluang), dan Threats (ancaman).

Tabel 1. Matriks Analisis SWOT

\begin{tabular}{|c|c|c|}
\hline OT $\mathrm{SW}$ & $\begin{array}{l}\text { Strengths } \\
\text { Tentukan 5-10 faktor- } \\
\text { faktor kekuatan internal }\end{array}$ & $\begin{array}{c}\text { Weakness } \\
\text { Tentukan 5-10 faktor- } \\
\text { faktor kelemahan internal }\end{array}$ \\
\hline $\begin{array}{c}\text { Opportunity } \\
\text { Tentukan 5-10 } \\
\text { faktor-faktor } \\
\text { peluang eksternal }\end{array}$ & $\begin{array}{c}\text { Strategi SO } \\
\text { Menggunakan kekuatan } \\
\text { untuk memanfaatkan } \\
\text { peluang }\end{array}$ & $\begin{array}{c}\text { Strategi WO } \\
\text { Ciptakan strategi yang } \\
\text { meminimalkan } \\
\text { kelemahan untuk } \\
\text { memanfaatkan peluang }\end{array}$ \\
\hline $\begin{array}{c}\text { Threats } \\
\text { Tentukan 5-10 } \\
\text { faktor-faktor } \\
\text { ancaman } \\
\text { eksternal }\end{array}$ & $\begin{array}{c}\text { Strategi ST } \\
\text { Ciptakan strategi yang } \\
\text { menggunakan kekuatan } \\
\text { untuk mengatasi } \\
\text { ancaman }\end{array}$ & $\begin{array}{c}\text { Strategi WT } \\
\text { Ciptakan strategi yang } \\
\text { meminimalkan } \\
\text { kelemahan untuk } \\
\text { mengatasi ancaman }\end{array}$ \\
\hline
\end{tabular}

(Freddy, 2015).

Matriks SWOT berguna untuk menggambarkan secara jelas bagaimana peluang dan ancaman eksternal yang dihadapi dapat disesuaikan dengan kekuatan dan kelemahan yang dimilikinya.

\section{HASIL PENELITIAN DAN PEMBAHASAN}

Hasil penelitian ini didapatkan dari: 1) observasi untuk mengetahui kelemahan, kekuatan, peluang dan ancaman tentang prodi Tadris Matematika IAIN Curup dalam mewujudkan guru matematika yang islami, kompetitif, dan profesional; 2) wawancara dengan Plt. Penanggung Jawab Prodi Tadris Matematika dalam hal ini ketua peneliti sendiri yang berperan sebagai informan utama, Plt. Ketua Jurusan 
150 | Mutia dan Arbaini: Tantangan, Harapan, dan Peluang Tadris Matematika...

Tarbiyah, staff prodi Tadris Matematika, dosen-dosen tadris Matematika IAIN Curup, Kepala Madrasah Kementerian Agama dan Kepala Dinas Tadris dan Kebudayaan Rejang Lebong dan Kepahiang, guru-guru matematika dan siswa SMP dan SMA Rejang Lebong dan Kepahiang, dan mahasiswa IAIN Curup, serta 3) dokumentasi berupa Kurikulum Kerangka Kualifikasi Nasional (KKNI) Tadris Matematika STAIN Curup Tahun 2017-2021 (sekarang menjadi IAIN Curup), keterbutuhan dosendosen matematika di tadris Matematika IAIN Curup, guru-guru matematika di Rejang Lebong dan Kepahiang serta dokumentasi lainnya yang kemudian dianalisis secara deskriptif kualitatif menggunakan SWOT.

Untuk mewujudkan guru matematika yang islami, profesional, dan kompetitif tersebut bukanlah suatu hal yang mudah bagi Tadris Matematika IAIN Curup. Banyak tantangan dan hambatan yang akan dirasakan Tadris Matematika untuk mencapai itu semua. Namun, orang bijak sering mengatakan bahwa kita harus dapat menyiasati hidup dengan mengubah setiap tantangan yang kita hadapi menjadi peluang untuk berbuat sesuatu. Oleh sebab itu, perlu dilakukan analisis kekuatan dan kelemahan prodi Tadris Matematika untuk mengantisipasi tantangan dan menciptakan sebuah peluang dengan menggunakan analisis SWOT. Analisa SWOT (SWOT analysis) adalah suatu metode perencanaan strategis yang digunakan untuk mengevaluasi faktor-faktor yang menjadi Kekuatan (Strengths), Kelemahan (Weakness), Peluang (Opportunities), dan Ancaman (Threats) yang mungkin terjadi dalam mencapai suatu tujuan dari kegiatan proyek/kegiatan usaha atau institusi/lembaga dalam skala yang lebih luas.

\section{Analisis SWOT Tadris Matematika dalam Mewujudkan Guru Matematika yang Islami, Profesional, dan Kompetitif}

Adapun kekuatan dan kelemahan yang dimiliki tadris matematika dalam mewujudkan guru matematika yang islami, profesional, dan kompetitif adalah sebagai berikut: 
Tabel 2. Analisis SWOT Tadris Matematika

\begin{tabular}{|c|c|}
\hline Kekuatan & Kelemahan \\
\hline $\begin{array}{lll}\text { Tadris } & \text { Matematika IAIN } & \text { Curup } \\
\text { telah memiliki mata kuliah } \\
\text { keislaman }\end{array}$ & $\begin{array}{l}\text { Muatan kurikulum mata kuliah ke- } \\
\text { matematikaan belum terintegrasi } \\
\text { keislaman }\end{array}$ \\
\hline $\begin{array}{l}\text { Dosen-dosen tadris matematika } \\
\text { selalu bertanggung jawab dan } \\
\text { melaksanakan tugas dengan baik } \\
\text { dan ikhlas baik dalam pengajaran, } \\
\text { penelitian, maupun pengabdian }\end{array}$ & $\begin{array}{l}\text { Belum semua dosen memulai } \\
\text { perkuliahan dengan membaca } \\
\text { Alquran }\end{array}$ \\
\hline $\begin{array}{ll}\text { Selama menyampaikan materi, } \\
\text { dosen selalu menyampaikan } \\
\text { materi dengan sungguh-sungguh } \\
\text { dan sesuai dengan silabus }\end{array}$ & $\begin{array}{l}\text { Belum semua dosen } \\
\text { menghubungkan tema yang } \\
\text { dipelajari dengan nilai-nilai Ilahi }\end{array}$ \\
\hline $\begin{array}{l}\text { Dosen-dosen selalu memberikan } \\
\text { keteladanan kepada mahasiswa } \\
\text { seperti dalam hal berpakaian dan } \\
\text { etika sopan santun }\end{array}$ & $\begin{array}{l}\text { Belum semua dosen menguasai } \\
\text { TIK dengan baik }\end{array}$ \\
\hline $\begin{array}{l}\text { Dosen-dosen } \\
\text { meningkatkan }\end{array}$ & $\begin{array}{l}\text { Masih kurangnya minat dosen } \\
\text { melakukan penelitian, pengabdian, } \\
\text { dan publikasi ilmiah; }\end{array}$ \\
\hline $\begin{array}{l}\text { Dosen-dosen selalu memberikan } \\
\text { penilaian hasil evaluasi belajar } \\
\text { dan bertindak seobjektif mungkin }\end{array}$ & $\begin{array}{l}\text { Belum semua dosen melakukan } \\
\text { pengembangan bahan ajar }\end{array}$ \\
\hline $\begin{array}{l}\text { Dosen-dosen selalu menjadi } \\
\text { contoh yang baik bagi mahasiswa } \\
\text { seperti tidak menghardik, tidak } \\
\text { menghina, tidak mencaci, dan lain } \\
\text { sebagainya }\end{array}$ & \\
\hline $\begin{array}{l}\text { Dosen-dosen selalu bersikap } \\
\text { ramah, senyum, mengucapkan }\end{array}$ & \\
\hline
\end{tabular}




\begin{tabular}{|l|l|}
\hline salam, dan menjalin hubungan & \\
yang baik dengan mahasiswa & \\
\hline Dosen-dosen sudah menguasai & \\
materi, struktur, konsep, dan pola & \\
pikir keilmuannya serta telah & \\
menguasai standar kompetensi & \\
dan kompetensi dasar mata & \\
pelajaran bidang yang diampu & \\
\hline
\end{tabular}

Selain itu, Prodi Tadris Matematika dalam mewujudkan Guru Matematika yang Islami, Profesional, dan Kompetitif juga memiliki kekuatan sebagai berikut 1) memiliki visi, misi, tujuan, tugas, dan target yang jelas; 2) visi, misi, tujuan, tugas, dan target prodi mengacu pada visi, misi IAIN Curup; 3 ) merupakan satu-satunya prodi tadris matematika di Kabupaten Rejang Lebong dan Kabupaten di sekitarnya yang berbasis keislaman; 4) terdapat SITRA (Sistem Informasi Terintegrasi Akademik); 5) telah melakukan beberapa kerja sama dengan institusi lainnya dalam hal seminar, penelitian, dan lain sebagainya; 6) kemampuan belajar mahasiswa tinggi dan memiliki latar belakang sosial dan budaya yang berbeda sehingga dapat memperkaya karakter mahasiswa; 7) tersedianya beasiswa untuk mahasiswa yang tidak mampu dan berprestasi; 8) mahasiswa aktif mengikuti kegiatan akademik maupun non akademik; 9) hubungan yang baik antara mahasiswa, dosen, dan staff; 10) rekrutmen dosen sudah sesuai dengan aturan pengadaan PNS sehingga mampu menyediakan dosen dan pegawai yang memiliki kompetensi tinggi di bidangnya; 11) semua dosen sudah berkualifikasi pendidikan S2; 12) bidang keilmuan dosen sesuai dengan Program Studi; 13) dosen telah memiliki publikasi ilmiah nasional; 14) struktur dan isi kurikulum disusun berdasarkan Kerangka Kualifikasi Nasional (KKNI) dan menunjukkan fleksibilitas mata kuliah dengan bobot mata kuliah pilihan; dan 15) dosen memiliki kemampuan yang baik dalam melakukan penelitian, pengabdian, dan publikasi ilmiah. 
Sedangkan kelemahan lainnya diantaranya: 1) kecepatan akses informasi masih terbatas; 2) bahan ajar kuliah masih minim; 3) belum ada dosen berpendidikan S3; 4) belum memiliki lulusan; dan 5) masih sedikitnya jumlah publikasi ilmiah dosen pada jurnal nasional dan internasional.

Proses pembelajaran di Prodi Tadris Matematika menekankan adanya keterlibatan aktif mahasiswa yang menjadi bagian penting bagi keberhasilan penyelenggaraan proses pembelajaran. Keterlibatan mahasiswa yang dimaksudkan dapat dilihat dari hal-hal berikut ini: 1)mahasiswa terlibat aktif dalam proses perkuliahan baik di dalam maupun di luar kelas dalam bentuk kegiatan diskusi kelompok, presentasi kelompok, yang akan dilanjutkan dengan diskusi kelas; 2) evaluasi proses pembelajaran yang menggunakan metode kuesioner. Mahasiswa diminta memberikan respon dalam bentuk kuesioner pada pertemuan terakhir perkuliahan. Hal ini dimaksudkan untuk mengevaluasi kualitas proses perkuliahan yang diberikan oleh dosen pengampu serta materi yang digunakan.

Selain kuliah, dosen tetap di prodi tadris matematika juga aktif dalam berbagai kegiatan seperti penelitian, dan publikasi ilmiah serta kegiatan pengabdian masyarakat baik yang dibiayai oleh Dana DIPA maupun dana mandiri. Setiap tahun dosen matematika terlibat aktif mengikuti kompetitif penelitian dan pengabdian yang diadakan oleh Pusat Penelitian dan Pengabdian Masyarakat (P3M) IAIN Curup. Selain itu, dosen juga aktif menulis di berbagai jurnal nasional. Namun meskipun aktif dalam kegiatan penelitian, pengabdian, dan publikasi ilmiah, prodi tadris matematika belum memiliki banyak penelitian. Sejak tahun 2017 baru memiliki 2 (dua) penelitian dari dosen tadris matematika yang dibiayai oleh DIPA kampus dan 2 (dua) penelitian dari biaya mandiri. Keterlibatan mahasiswa dalam penelitian dosen juga belum ada. Dari segi publikasi ilmiah, publikasi ilmiah dosen dalam satu tahun ini cukup baik, sudah tercatat cukup banyak yang menulis di jurnal/prosiding nasional dan ada yang sedang menuju internasional. Sedangkan pengabdian belum tercatat banyak. 
154 | Mutia dan Arbaini: Tantangan, Harapan, dan Peluang Tadris Matematika...

Untuk lulusan prodi tadris matematika saat ini belum ada karena baru memiliki dua angkatan sehingga prodi tadris matematika belum memiliki alumni.

Lulusan prodi pendidikan matematika diharapkan memiliki kompetensi dasar guru agar dapat diterapkan pada saat terjun ke lapangan, profesional, dan islami sehingga mampu berkompetisi dengan lulusan perguruan tinggi lainnya. Selain itu, lulusan diharapkan dapat menjunjung tinggi nilai-nilai etika dan integritas yang diperoleh selama berkuliah di prodi tadris matematika IAIN Curup.

Dwi Inayati Kaltsum yang merupakan guru matematika di salah satu sekolah di Kabupaten Kepahiang menyatakan bahwa lulusan prodi tadris matematika IAIN Curup nanti hendaknya memiliki kemampuan matematika yang baik dan didukung dengan kemampuan agama islam juga yang baik agar dapat terintegrasi dengan baik, karena saat ini guru sangat penting memiliki keahlian itu apalagi saat ini telah dilaksanakan Kompetensi Siswa Madrasah (KSM) setiap tahun. Selain itu, lulusan juga diharapkan memiliki kemampuan literasi dan High Order Thinking Skills (HOTS) agar dapat berkompetisi dengan lulusan lainnya.

Selain itu, Dina Oktarina menyatakan bahwa tidak hanya faktor guru yang mempengaruhi kualitas pendidikan. Di antaranya ada kurikulum, anggaran pendidikan, siswa itu sendiri, teknologi informasi dan komunikasi, dan lain-lain. Namun, kualitas pendidikan ditentukan pertama kali saat di jenjang pendidikan dasar. Adapun salah satu upaya yang dilakukan sekolah dalam perbaikan kualitas dan mutu peserta didik tersebut adalah dengan memperbaiki proses pembelajaran menggunakan strategi-strategi belajar yang cocok dengan karakter siswa, sebab guru dan siswa merupakan satu kesatuan yang saling mempengaruhi. Selain itu, pelaksanaan kurikulum yang secara utuh dan baik juga sangat mempengaruhi kualitas pendidikan meskipun dalam implementasinya mengalami kendala-kendala seperti sulitnya mengaplikasikannya dalam pembelajarannya, kemampuan siswa yang tidak sama dan apalagi saat ini ada sistem zona lingkungan dalam menerima siswa baru sangat mempengaruhi. 
Berdasarkan keterangan guru-guru tersebut, maka kebutuhan akan guru matematika yang islami, kompetitif, dan profesional sangat dibutuhkan apalagi dengan adanya perubahan kurikulum tersebut, maka kompetensi, profesionalitas, dan karakter guru harus terus ditingkatkan. Jika mengacu pada visi dan misi prodi Tadris Matematika IAIN Curup yaitu Pada tahun 2037 menjadi program studi bermutu dan terkemuka dalam menghasilkan Pendidik Matematika yang Islami, Profesional, dan Kompetitif pada jenjang pendidikan menengah di wilayah Sumatera, maka ini merupakan sebuah tugas besar prodi tadris matematika dan institusi untuk mewujudkannya yang juga tentunya membutuhkan kerja sama dengan pemerintah daerah dan beberapa stakeholder lainnya yang terkait.

Melihat keadaan pembelajaran matematika di sekolah-sekolah, ada beberapa kondisi yang dapat dijelaskan sebagai berikut: 1) matematika masih merupakan momok bagi siswa dalam pembelajaran di sekolah bahkan perguruan tinggi karena sifatnya yang abstrak dan sulit dipahami. Matematika adalah disiplin ilmu yang mempelajari tentang cara berpikir dan mengolah logika, baik secara kuantitatif maupun secara kualitatif. NCTM (National Council of Teachers of Mathematics) merekomendasikan 4 (empat) prinsip yaitu a) matematika sebagai pemecahan masalah; b) matematika sebagai penalaran; c) matematika sebagai komunikasi; d) matematika sebagai hubungan (Suherman, 2003). Sehingga itulah yang menyebabkan matematika menjadi sulit dan menjadi tugas besar bagi guru matematika untuk menyampaikan matematika agar tidak menjadi momok lagi di masa mendatang; 2) tuntutan perubahan kurikulum yang berubah-ubah. Apalagi kurikulum saat ini menuntut siswa untuk berpikir tingkat tinggi dan mandiri, sedangkan siswa masih perlu banyak bimbingan dalam pembelajaran matematika terkait konsep dasar yang dimiliki oleh matematika dan saling berkaitan antar materi; 3) adanya sistem zona baru dalam penerimaan siswa baru yaitu zona lingkungan, sehingga ada beberapa sekolah yang merasa terkendala dengan kondisi kemampuan siswa yang heterogen; 4) matematika masih menjadi salah satu penentu nilai Ujian Nasional siswa 
156 | Mutia dan Arbaini: Tantangan, Harapan, dan Peluang Tadris Matematika...

di sekolah, sehingga siswa terus berupaya mendapatkan nilai terbaik (hasil) pada mata pelajaran matematika dan bukan proses; 5) adanya integrasi matematika dengan ilmu lain-lain, sehingga siswa tidak hanya menguasai matematika saja tetapi juga tentang nilai-nilai keislaman; 6) tuntutan penguatan karakter dalam setiap materi pembelajaran matematika sehingga guru harus berupaya meningkatkan softskills dan hardskills siswa; 7) penguatan konsep matematika di tingkat dasar agar di tingkat menengah guru tidak mengalami kesulitan saat menyampaikan materi dan siswa juga bisa mengikuti materi selanjutnya dengan baik; 8) adanya kegiatan-kegiatan esktrakurikuler siswa sehingga waktu siswa terbagi untuk belajar dan jarang membuka kembali materi di rumah; 9) kurangnya perhatian orang tua terhadap kegiatan belajar siswa di rumah maupun sekolah; 10) masih terbatasnya sarana dan prasarana pembelajaran di sekolah khususnya sekolah-sekolah di daerah terpencil; 11) sulitnya mencari guru matematika, sebab kualifikasi pendidikan guru yang mengajar matematika saat ini tidak semuanya berasal dari pendidikan matematika, ada yang berasal dari kualifikasi pendidikan biologi, fisika, Pendidikan Agama Islam, dan lainnya; 12) sulitnya penjaringan guru matematika melalui tes CAT karena passing grade yang tinggi; 13) berkembangnya program studi tadris matematika di Provinsi Bengkulu dan Sumsel; dan 14) tuntutan persaingan dunia global pada mutu lulusan.

Matematika merupakan mata pelajaran yang masih sulit dirasakan siswa hingga mahasiswa saat ini. Jika siswa tidak menyukai matematika sejak tingkat dasar, maka akan sulit bagi siswa untuk melanjutkan ke tingkat menengah apalagi perguruan tinggi, sehingga mahasiswa yang mengambil jurusan matematika di perguruan tinggi masih tergolong rendah bahkan untuk tingkat pendidikan doktor saja saat ini sangat sulit. Oleh sebab itu, tidak mudah untuk mendapatkan calon guru matematika di tingkat perguruan tinggi kecuali sudah sangat memiliki minat dan kesukaan yang sangat tinggi terhadap matematika tersebut. Bahkan saat mewawancarai mahasiswa tadris matematika IAIN Curup, mereka menyatakan bahwa tidak semua dari mereka memilih matematika sebagai 
pilihan utama dalam masuk perguruan tinggi. Ada yang karena dipaksakan orang tua dan ada juga karena tidak ada pilihan lain. Sehingga prodi mesti berusaha keras melakukan strategi-strategi untuk mengatasi rendahnya minat tersebut, salah satunya adalah dengan terus meningkatkan kualitas dosen agar dapat melahirkan calon-calon guru yang berkualitas juga. Dengan demikian, melihat fenomena tersebut, kebutuhan akan guru dan bahkan dosen matematika pun juga sangat tinggi apalagi dalam upaya meningkatkan kualitas pendidikan dan karakter bangsa.

Kadar Najmiddin, Jernilan, and Zikrullah (2017) menyatakan bahwa guru-guru yang mengajar matematika di tingkat SMPN/MTsN dan SMAN/MAN tidak semuanya berlatar belakang matematika dikarenakan kekurangan guru untuk mengajar di matematika sementara jam pelajaran matematika banyak sehingga tidak seimbang. Tidak hanya itu, guru-guru matematika yang mengajar di madrasah pun sangat sedikit sekali. Hal ini tentunya sangat memprihatinkan bagi matematika. Sedangkan tuntutan pembelajaran matematika semakin tinggi.

Dengan adanya kekuatan dan kelemahan tersebut, maka dapat menjadi peluang bagi mahasiswa dalam mewujudkan guru matematika yang islami, profesional, dan kompetitif, sebab mahasiswa adalah calon guru yang dicetak oleh prodi tadris matematika. Dengan adanya kekuatan-kekuatan tersebut maka dapat mengatasi kelemahan-kelemahan yang ada.

\section{Peluang Tadris Matematika}

Kabupaten Rejang Lebong dan Kabupaten Kepahiang merupakan bagian dari Kabupaten yang ada di propinsi Bengkulu yang berbatasan dengan Kabupaten Bengkulu Utara dan Propinsi Sumatera Selatan khususnya kota Lubuk Linggau. IAIN Curup berada di pusat Kabupaten Rejang Lebong, tepatnya di Kecamatan Curup yang merupakan ibu kota Kabupaten Rejang Lebong.

Tadris Matematika adalah unit pelaksana tugas dan fungsi pokok bidang akademik dalam struktur kelembagaan IAIN Curup yang 
158 | Mutia dan Arbaini: Tantangan, Harapan, dan Peluang Tadris Matematika...

menyelenggarakan dan mengelola tadris tinggi setingkat Sarjana di bidang keilmuan matematika dan berdiri sejak tahun 2017 yaitu dengan keluarnya Surat Keputusan (SK) mengenai pendirian prodi Tadris Matematika.

Di Kabupaten Rejang Lebong, Prodi Tadris Matematika merupakan salah satu program studi yang sedikit jumlah mahasiswanya karena dianggap sulit dan lama menyelesaikannya. Sejak duduk di bangku Sekolah Dasar, siswa telah menganggap matematika itu sulit dan bahkan selalu dihindari. Matematika merupakan pelajaran yang abstrak, sulit untuk dipahami jika tidak memiliki konsep yang baik sehingga membutuhkan strategi belajar matematika yang baik pula agar siswa dapat memahami materi. Fakta menunjukkan bahwa kesulitan belajar matematika justru menjadi peluang besar daripada program keguruan lainnya yaitu salah satunya memiliki peluang kerja yang besar menjadi seorang guru di berbagai jenjang mulai dari Sekolah Dasar (SD)/ Madrasah Ibtidaiyah (MI), Sekolah Menengah Pertama (SMP)/Madrasah Tsanawiyah (MTs), dan Sekolah Menengah Atas (SMA)/Madrasah Aliyah (MA). Berbeda dengan lulusan umum, lulusan dari program keguruan yang berwawasan Islam tentu memiliki keistimewaan sendiri. Kebutuhan ideal guru-guru yang merupakan lulusan tadris memiliki peluang lebih besar sebab hanya Fakultas/Jurusan Tarbiyah yang bisa menyiapkannya, baik melalui jurusan tadris di IAIN/STAIN atau jurusan umum di UIN. Selain itu, mengingat adanya perubahan paradigma madrasah dari sekolah agama menjadi sekolah umum berciri khas agama Islam sehingga membutuhkan guru yang memiliki kompetensi ganda yaitu dapat mengajarkan pengetahuan umum yang berwawasan Islam seperti mengintegrasikan matematika dengan keislaman dan lain sebagainya yang dapat dikaitkan antara pengetahuan umum dengan Islam. Inilah peluang yang bisa diisi oleh lulusan jurusan umum IAIN/STAIN, khususnya jurusan tadris. Peluang ini sangat terbuka mengingat pendirian madrasah dalam semua jenjang akhir-akhir ini semakin meningkat seiring kian membaiknya perhatian pemerintah terhadap pengembangan pendidikan Islam. 
Selain itu, peluang lainnya adalah dapat membuka beberapa bimbingan belajar dan faktanya, mata pelajaran matematika menjadi langganan prioritas dalam program-program bimbingan belajar tersebut. Dengan kata lain, peluang mendapat pekerjaan lebih banyak. Harapan dan peluang untuk menjadi dosen juga sangat terbuka lebar meskipun dengan syarat harus melanjutkan ke jenjang S2.

\section{Strategi-Strategi yang dilakukan Tadris Matematika}

Untuk mewujudkan guru matematika yang islami, kompetitif, dan profesional, tadris matematika melakukan strategi-strategi baik secara internal maupun eksternal dengan berkoordinasi dengan pemerintah daerah, sekolah-sekolah, dinas pendidikan dan kebudayaan, kementerian agama, dan institusi-institusi. Berikut strategi-strategi yang dilakukan prodi untuk mengatasi kelemahan, mengantisipasi tantangan, dan mewujudkan sebuah peluang tadris matematika dalam mewujudkan guru matematika yang islami, kompetitif, dan profesional.

Tadris Matematika IAIN Curup memang telah memiliki mata kuliah umum tentang matematika dan mata kuliah keislaman, hanya saja belum terintegrasikan dengan baik. Oleh sebab itu, dilakukan upaya penguatan untuk mewujudkan itu salah satunya adalah dengan melakukan workshop atau seminar tadris matematika mengenai integrasi matematika dan Alquran sebagai upaya awal untuk memulai pembelajaran matematika yang terintegrasi dengan Islam, lalu kemudian diikuti dengan pembelajaran matematika yang selalu dikaitkan dengan nilai-nilai keislaman atau dihubungkan dengan ayat-ayat suci Alquran sehingga kemudian juga dapat meningkatkan nilai-nilai karakter mahasiswa.

Sebagai pencetak guru matematika di masa mendatang, maka Tadris Matematika IAIN Curup yang memiliki visi ingin mewujudkan guru matematika yang islami, profesional, dan kompetitif selalu berupaya melakukan berbagai strategi untuk menghadapi kelemahan-kelemahan, tantangan, dan juga tuntutan globalisasi tersebut yaitu dengan meningkatkan kompetensi keilmuan mahasiswa khususnya pada keilmuan matematika dan dapat mengintegrasikannya dengan keislaman, 
160 | Mutia dan Arbaini: Tantangan, Harapan, dan Peluang Tadris Matematika...

melakukan pembelajaran yang aktif, interaktif, menyenangkan, holistik, integratif, saintifik, kontekstual, tematik, efektif, kolaboratif, dan berpusat pada mahasiswa (Student Centered Learning), mendorong mahasiswa ikut aktif dalam berbagai kegiatan mahasiswa yang diselenggarakan oleh IAIN Curup atau institusi lain seperti mengikuti lomba-lomba matematika antar mahasiswa, lomba karya tulis ilmiah, dan kegiatan lainnya yang dapat meningkatkan kompetensi mahasiswa, melibatkan mahasiswa dalam kegiatan penelitian dan pengabdian dosen, dan memberikan kesempatan kepada mahasiswa untuk melakukan pengabdian masyarakat agar dapat menyampaikan ilmunya dengan metodenya masing-masing sehingga terbiasa dalam mengajar,

Untuk mengembangkan kompetensi dosen, dosen diberikan pelatihan/workshop tentang penulisan bahan ajar atau memberikan kesempatan kepada para dosen untuk mengikuti pelatihan/workshop penulisan bahan ajar di institusi lain yang menyelenggarakan, memberikan peluang dan memfasilitasi dosen mengikuti workshop/lokakarya penulisan proposal untuk dapat berkompetisi mendapatkan jumlah penelitian dan dana penelitian yang lebih banyak, meningkatkan kemampuan publikasi ilmiah dosen, memberikan kesempatan seluas mungkin kepada dosen untuk meningkatkan kualitasnya seperti mengikuti pelatihan-pelatihan, seminar nasional dan internasional serta organisasi profesi sesuai dengan bidang keilmuannya, memberikan izin kepada dosen untuk melanjutkan studi ke jenjang yang lebih tinggi, memberikan izin kepada dosen dan mahasiswa untuk mengembangkan dan menggali pengetahuan dan informasi dengan mengikuti program pertukaran mahasiswa dan dosen, serta meningkatkan kerjasama dengan berbagai institusi dan lembaga pendidikan.

\section{SIMPULAN}

Tadris Matematika adalah unit pelaksana tugas dan fungsi pokok bidang akademik dalam struktur kelembagaan IAIN Curup yang menyelenggarakan dan mengelola tadris tinggi setingkat Sarjana di bidang keilmuan matematika dan berdiri sejak tahun 2017. Proses 
pembelajaran matematika yang dapat dilihat saat ini masih menjadi momok yang menakutkan bagi sebagian besar siswa apalagi faktor-faktor eksternal yang sudah menuntut kualitas pendidikan dan karakter bangsa yang lebih baik sehingga menyebabkan pembelajaran menjadi semakin sulit seperti implementasi kurikulum 13 dan evaluasi penilaian pembelajarannya yang tidak hanya memberatkan siswa akan tetapi juga guru dalam membuat perangkat pembelajaran dan penilaian pembelajaran. Oleh sebab itu, sebagai prodi yang memiliki tugas mencetak calon guru matematika yang islami, kompetitif, dan profesional harus memiliki komitmen yang tinggi untuk mewujukan hal tersebut yang sekaligus merupakan visi dari prodi tadris matematika.

Untuk mewujudkan guru matematika yang islami, profesional, dan kompetitif tersebut bukanlah suatu hal yang mudah bagi Tadris Matematika IAIN Curup. Banyak tantangan dan hambatan yang akan dirasakan Tadris Matematika untuk mencapai itu semua. Namun, orang bijak sering mengatakan bahwa kita harus dapat menyiasati hidup dengan mengubah setiap tantangan yang kita hadapi menjadi peluang untuk berbuat sesuatu. Oleh sebab itu, perlu dilakukan analisis kekuatan dan kelemahan prodi Tadris Matematika untuk mengantisipasi tantangan dan menciptakan sebuah peluang dengan menggunakan analisis SWOT. Analisa SWOT (SWOT analysis) adalah suatu metode perencanaan strategis yang digunakan untuk mengevaluasi faktor-faktor yang menjadi Kekuatan (Strengths), Kelemahan (Weakness), Peluang (Opportunities), dan Ancaman (Threats) yang mungkin terjadi dalam mencapai suatu tujuan dari kegiatan proyek/kegiatan usaha atau institusi/lembaga dalam skala yang lebih luas.

Ada beberapa hal yang perlu dilakukan sebagai upaya untuk mewujudkan guru matematika yang islami, profesional, dan kompetitif yaitu 1) prodi harus terus tetap meningkatkan kualitas dan kuantitas dosen dengan berbagai upaya dalam memenuhi kebutuhan tri dharma penelitian dosen; 2) mendapat dukungan penuh dari pimpinan untuk segala kegiatan yang berkaitan dengan peningkatan dan pengembangan prodi; 3) memfasilitasi segala sarana dan prasarana yang dibutuhkan oleh prodi; 4) 
162 | Mutia dan Arbaini: Tantangan, Harapan, dan Peluang Tadris Matematika...

meningkatkan softskills dan hardskill mahasiswa dengan mengikuti berbagai kegiatan akademik dan non akademik; dan 5) meningkatkan dan mewujudkan kerjasama dengan pemerintah daerah dan stakeholderstakeholder lainnya yang terkait terutama sekolah-sekolah sebagai lembaga pencetak calon-calon guru matematika yang islami, profesional, dan kompetitif.

\section{DAFTAR PUSTAKA}

Aslamiyah, Siti Suwaibatul. (2016). Profesionalisme Guru dalam Perspektif Islam, Akademika, 10(2), 173-186. Retrieved from http://journal.unisla.ac.id/pdf/131022016/3.\%20Siti\%20Suwaibatul $\% 20$ Aslamiyah,\%20Profesionalisme\%20Guru\%20dalam\%20Persep ektif\%20Islam.pdf

Haryono, and Amirul Hadi. (1998). Metodologi Penelitian Pendidikan. Jakarta: Pustaka Setia.

Inayati Kaltsum, Dwi. (2018). Wawancara Guru Matematika MAN 1 Kepahiang, dilakukan pada tanggal 15 September.

Murtiyasa, Budi. (2015). Tantangan Pembelajaran Matematika Era Global. Dipresentasikan dalam Seminar Nasional Matematika dan Pendidikan Matematika, UMS.

Najmiddin, Kadar, Jernilan, and Zikrullah. (2017). Kasi Pendidikan Madrasah Rejang Lebong dan Kepahiang serta Kabid PTK Kepahiang.

Oktarina, Dina. (2018). Wawancara Guru Matematika SMPN 3, dilakukan pada tanggal 15 September.

Pirdaus. (2017). Tantangan dan Peluang Pembelajaran Matematika dalam Upaya Turut Membangun Budaya dan Karakter Bangsa. Diakses pada bulan Oktober pukul 10.00. Retrieved from https://www.kompasiana.com/shoimatunnisfah/rendahnya-sdmberpengaruh-terhadap-pendidikan-generasi-muda_ 593b98a0519773585b0a923b.

Purnomo, Yoppy Wahyu. (2017). Menjadi Guru Matematika: Antara Peluang, Harapan, Tuntutan, dan Tantangan, Prosiding Conference 
Tadris Matematika Universitas Muhammadiyah Surakarta, November, 6(2).

Rangkuti, Ahmad Nizar. (2014). Tantangan dan Peluang Pembelajaran

Matematika, Logaritma II, 1(4). Retrieved from https://docplayer.info/72184035-Representasi-matematis-olehahmad-nizar-rangkuti-s-si-m-pd-1.html.

Rangkuty, Freddy. (2015). Analisis SWOT: Teknik Membedah Kasus Bisnis. Jakarta: PT. Gramedia Pustaka Utama.

Sagala, Syaiful. (2011). Konsep Dan Makna Pembelajaran. Bandung: Alfabeta.

Sepriyanti, Nana. (2012). Guru Profesional Adalah Kunci Mewujudkan Pendidikan Berkualitas. Al-Ta'lim, 1(1). Retrieved from ournal.tarbiyahiainib.ac.id/index.php/attalim/article/view/8

Suherman, Erman, and dkk. (2003). Strategi Pembelajaran Matematika

Kontemporer. Bandung: Jurusan Pendidikan Matematika Fakultas

Pendidikan Matematika dan Ilmu Pengetahuan Alam, Universitas Bandung.

Sugiyono. (2016). Memahami Penelitian Kualitatif. Bandung: Alfabeta.

Wawancara Dengan Kadis Madrasah Kementerian Agama Kabupaten

Rejang Lebong," pada tanggal Oktober 2017.

Keputusan Menteri Agama Nomor 370/1993 tentang Madrasah Aliyah.

Keputusan Menteri Agama Nomor /1992 tentang Kurikulum Madrasah.

Peraturan Pemerintah Nomor 28/1990 tentang Pendidikan Dasar. 
164 | Mutia dan Arbaini: Tantangan, Harapan, dan Peluang Tadris Matematika... 